\title{
COMIC STRIPS AND BOARD GAME AS A MEDIA IN LEARNING ORAL LANGUAGE SKILLS FOR STUDENTS
}

\author{
By: \\ Puan Suri Mira Annisa ${ }^{1)}$ \\ Rafika Dewi Nst ${ }^{2)}$ \\ State University of Medan, Medan 1,2) \\ E-mail: \\ puansuri19@gmail.com ${ }^{1)}$ \\ fildzafayyadh@gmail.com ${ }^{2)}$
}

\begin{abstract}
This research aims to find out the improvement of the students' oral language skills using comic strips and board game as an instructional media in terms of its physical feasibility, design, color, material, images and text by using role-playing. The subject was the 1 st grade students of the English department of Unimed, consisted of 30 students for the field trial. This research was use classroom action research by Kemmis and Taggart. It was accomplished in two cycles. Each cycles consisted of four steps: planning, action, observation and reflection. The first cycle consisted of one meeting including giving material and pretest. The second cycle consisted of one meeting, given material and post-test. Based on the students' assessment, it was showed that the mean of pre-test was 52 and the mean of post-test was 88. And the higher score was 92. From the data, it indicated that using Comic Strips and Board Game in learning Oral Language Skills was effective, and the data concluded that the students' have the improvement in speaking. The results showed that comic strips and board game were very good and feasible to be used as a media to learn oral language skills.
\end{abstract}

Keywords: comic strips, board game, media, oral language skills.

\begin{abstract}
ABSTRAK
Penelitian ini bertujuan untuk mengembangkan kemampuan siswa dalam pembelajaran Oral Language Skills dengan menggunakan Comics Strips dan Board Game sebagai media yang dirancang dengan berbagai design, warna, materi, gambar dan text yang mengunakan metode Role Playing. Subjek penelitian ini adalah mahasiswa jurusan pendidikan Bahasa Inggris Unimed semester 1 yang mengambil mata kuliah Oral Language Skills dengan jumlah 30 orang. Penelitian ini menggunakan metode Kemmis dan Taggart. Yang dilakukan dalam dua tahap. Pada setiap tahap terdiri atas empat tahap: Rencana, kegiatan, observasi dan Refleksi. Pada tahapan pertama terdiri dari satu pertemuan yaitu
\end{abstract}


memberikan materi dan pre Test. Pada tahap kedua terdiri dari satu pertemuan yaitu memberikan materi dan Post Test. Berdasarkan Hasil penilaian lembar jawaban siswa menunjukkan rata- rata nilai Pre Test mahasiswa 52 dan rata- rata Post Test mahasiswa 92. Hal ini menunjukkan bahwa penggunaan media dalam pembelajaran Oral Language Skills sangat efektif berdasarkan data menunjukkan adanya peningkatan nilai.. Hasil analisis menunjukkan bahwa Comic Strips dan Board Game merupakan media yang sangat bagus dan dapat digunakan sebagai media dalam pembelajaran Oral Language Skills.

Kata kunci: comic strips, board game, oral language skills, media.

\section{INTRODUCTION}

Oral Language Skills is subject of the study which is the combination between two skills, listening and speaking. Listening and speaking are always in integration, so lectures should teach these two skills in an interacted way. Although the students may know how to listen and speak in the language, they may still not be able to communicate in this language mainly because these skills are not used in integration. Use of media and real life situations could naturally lead to the integration of skills.

Learning media is used to support the material taught in the teaching-learning process. By using learning media, it is expected that the connection among the lecturers and students can be built in order to complete the purpose of learning.

The researcher has done a brief observation and interview the students, based on interviews found that students who were passive in the learning process complained because of a lack of confidence, pronunciation and grammar. The activities in the class did not give them the opportunity to explore their skills so it makes them difficulties in speaking. In the class the lecturer as a center of the learning and Oral
Language Skills Subject is more often done by finishing the exercises on the textbook. So the students did not practice speaking.

To overcome this problem, the lecturers need to find the effective way to teach Oral Language Skills. The lecturers should create a media to make students speak up. Many media can be used including games because many researches said that this media is effective to use in teaching speaking. Using game for learning Oral Language Skills subject will be effective way to make student speak up and speak well.

The Lecturer can use Comic Strips and Board Game as media in teaching and learning process. According to Hornby (1995:486) games is an activity that you do to have some fun. Comic Strips and Board Game consist of pictures which are good for teaching as Thornbury (2007:25) states that visualizing is the best way to teach new word for all subjects. By using a picture, the attention of students will be more focused. It means that pictures can create their inspiration and motivation to know the content of the message of those pictures.

Comic Strips are collections of pictures which have stories and consist of one or more title and 
theme. It is an art work that contains about characteristics, events in picture form which can be humorous, adventurous, etc and it is usual take place on books or newspaper.

Board Game is one of games that can be used in teaching speaking. Using that game will help to improve speaking ability and also make the student interest to the lesson. Board Game is a fun game to do in class.

Comic Strips and Board Game encourage the students to active in the class, entertain them, teach the language naturally, and promote fluency. So this media makes students confidence to speak English so they can speak fluently. The important of this activity that the students directly play the media through role playing so it makes the teaching learning process naturally.

Thus, the researcher is interested in using Comic Strips and Board Game as a media for Oral Language Skills, especially for the grade 1 of English Department Students, as an initial effort to help solving the problems in learning process. The media is expected not only as a tool for lecturers to deliver the material of the lesson, but it will also invite the students to participate in using it. It is expected that the Comic Strips and Board Game can be the alternative to improve the students' speaking skill.

The ability of students to learn to absorb material using the media images on the internet is very dependent on their desire to absorb the learning material Damanik D, Panjaitan J \& Simangunsong I
(2020), Purba D \& Sihombing H (2020).

\section{THEORY}

Oral Language Skills

Oral Language Skills is one of the subject matter which learning about the two main skills in second language learning, they are listening and speaking. The goal of teaching oral language skills is to improve student communication skill in order to be able to express their thought, ides, or feelings, and learn how to follow social rules in communication activities.

According to Nunan (2003) in Kayi (2006), the main aim in teaching speaking is to prepare the learners to be able to : 1) Produce the English sounds and speech patterns; 2) Use words and sentence stress, intonation patterns and the rhythm of the second language; 3) Select appropriate words and sentences according to the proper social setting, audience, situation, and the subject matter; 4) Organize their thoughts in a meaningful and logical sequence; 5) Use language as a means of expressing values and judgments; 6)Use the language quickly and confidently with view unnatural pauses, which is called fluency.

Teaching Oral Language Skills is a very important part of second language learning. The ability to communicate in a second language clearly and efficiently contributes to the success of the learner in university and success later in every phase of life. Therefore, it is essential that lecturers pay great attention to teaching listening and speaking. Rather than leading 
students to pure memorization, providing a rich environment where meaningful communication takes place is desired. With this aim, various listening and speaking activity can contribute a great deal to students in developing basic interactive skills necessary for life. The activity in oral language skills subject make students more active in the learning process and at the same time make their learning more meaningful and fun for them.

\section{Teaching Using Media}

The problem for most students to learn English is lack of interest. They perceive English as something difficult to understand. It is important for teacher to find a teaching media that can attract students' attention, because it will be easier for teacher to deliver the material when students pay attention to their teaching.

Media is derived from Latin and is the plural of the word "medium" which literally means "intermediary" that is the intermediary of the message source by receiving the message (Susilana and Riyana, 2009: 6). Media also means tools that can simplify the job (Rusman, 2013: 159). Media attract the students' attention. It becomes supplementary verbal information and illustrates relationships in a way that is impossible with words. Media can be interesting to watch challenging, and reinforcing (Davies, 1980:193). From the definitions of media above, it can be concluded that media can ease the process of delivering message, particularly from teachers to students.
There are some characteristics of good media as proposed by Sudjana and Rivai (2009:4). They are:

1. Match with the teaching objectives

Learning media are chosen based on instructional objectives. Those instructional objectives include understanding, application, and analysis.

2. Support the content of the materials

The materials that include facts, principles, and generalization need media in order that the students will understand the material easily.

3. Easy to obtain

Media that are needed by the teachers should be easy to get. At least the media are easy to be designed by the teachers.

4. Easy to use

There are many kinds of media, but the important thing is that the teachers do not know how to use the media, they are useless. Therefore, good media should be easy to be used and they are not too complicated.

5. Match with the students' intelligence

Media should be appropriate with the students intelligence, so the materials can be understood easily by the students.

Suyanto (2007:102) states that there are three kinds of Media:

1. Audio Media is media that contaion recorded text to listen. It means the audio media has sound which is listened by us and to mean as thinking that the content message in audiotape from such as vocal cord/tape 
recorder and video compact disk which can stimulate thought, feeling, idea of the stuents in teaching and learning process.

For example: Radio, Audio tapes/cassetts, etc.

2. Visual media is term used to include teaching aids which depend on the use visual communication

channel.Simulation of visual media fortunately give students result of teaching and learning more effective and efficient as good as possible as like reremembering and knowing the material, according Levie and Lenzt (2013: 192). Visual media are able to make easily understanding and unifying of remembering.

For example: flat material ( pictures, flash cards, maps, charts, cardboard figures); Three-dimension materials( Realia, puppets, models); Projected material (Slides, overhead projectors, film strips)

3. Audio-Visual Media is media that can be seen, touched, and listened.

\section{Comic Strips}

Comic Strips is an art work that contains about characteristics, events in picture form which can be humorous, adventurous, etc. According to Gavigan and Tomasevich (2011:9), comic strips are short form comics which generally consist of three to eight panels. They usually appear in newspapers.

Basically, a comic strip has the same essential elements as a comic book page. Those elements are panel, lettering, word balloon, thought balloon, caption, sound effects, borders, and gutters (Yomtov, 2014: 5). Panel is the most basic element of a comic. It is defined as a single image in a sequence of images. It has various types such as square, round, triangular and the like.

There are several advantages of using comic strips as media in learning speaking. As stated by Carry (2004: 58), in comics, readability measures are determined not only on words alone, but also on pictures. Here, pictures support the words to make speaking becomes more comprehensible. Second, the pictures are used not only to aid comprehension but also to facilitate vocabulary teaching. They help the students a lot to memorize and recall words. Csabay (2006) explains that if a word, expression, or concept is accompanied by a picture, the learner will memorize and recall it more easily. Besides comprehension and vocabulary, Csabay (2006) asserts further that grammatical competence can be improved as well. With the help of comic strips, new grammatical points can be introduced and practiced. With the use of comic as a medium in teaching English, the students do not realize that they are learning English. They learn English in more enjoyable and interesting ways.

\section{Board Game}

Board game can be offered as a teaching aid to teach English. It is Board is the popular types of games among the children. Board games are well known almost in all of societies in the world. According to Pritchard 
(1994), the origins of board games came from China, India, or Nigeria. The examples of popular board games are monopoly, snakes and ladders, and luda. This type of the board game mainly involves moving markers along a path (Lewis and Bedson, 1999). Board games are a kind of games that can be used in teaching language. Rahmawati (2012) states board games are also been used to teach children basic fact and information about the world in which they live. In the board game, there are some materials needed by the player such as, counters, dice, game board, and cards.

Board game gives many advantages for the lecturer and the students. The advantages of board games for the lecturer are helping the lecturer to get the students involved and get more positive proactive responses, enhancing students' motivation because it is contrast with the regular class exercises, and adding students' interest to what they do not normally find interesting. Whereas, some of advantages of board game for the students are the board games provide rich learning opportunities and improve their learning ways, connect to the real life situations, encourage the use of authentic materials and guarantee fresh content, enhance their motivation as they perceive them as fun and enjoyable, help them to be more creative, tap into the emotional side, etc.

According to Carly (2010: 21) there are many advantages of using board games, such as:

1. Bringing real world context into the classroom, and increasing students' use of English in a flexible, meaningful and communicative way.

2. Involving friendly competition and keeping students interested in learning the language.

3. Helping students learn and hang on to new words more easily.

4. Motivating and challenging.

5. Learning a language requires a great deal of effort.

6. Encouraging students to interact and communicate.

7. Creating a meaningful context for language use.

\section{Using Comic Strips and Board Game in teaching Oral Language Skills.}

In order to achieve the goal of English teaching-learning, the instructional process should be designed to meet the students' needs and also accommodate their learning style. Lecturers are expected to be creative in developing the materials and also the media to support the teaching-learning process.

Through media, the students can increase their idea and creativity. It can even encourage them to speak more. Nowadays, the needs of media in language learning become an important thing. The media can be used as one way for solving the problems in speaking. Pictures and the variations, as what is included in Comic Strips and Board Game as the examples of visual media, can help lecturer teaching Oral Language Skills to the students.

Comic Strips and Board Game design should adopt the learning theories so that it can meet the students' needs and learning styles. Moreover, the teaching media should also be tested and evaluated. 


\section{RESEARCH}

\section{METHODOLOGY}

\section{The Subject of Research}

The subject of this research was the first grade students of English Department at Unimed in academic year 2018/2019. There were 30 students and learn Oral Language Skills.

\section{The Source of Data}

Arikunto (2002) states that data are the result of the fact and number that can be substanced to arrange the information. Data refers to the rough materials researchers collect from the world they are studying; they are the particular that form the basis of analysis. Data include materials the people doing the study actively record. In other words, data are the information that gained from the subject of the research. Here, the data were the existing materials and the student's need.

Moreover, the data sources are the subject from which the data can be gained (Arikunto, 2006). Therefore, the source of data is the subject that becomes the source of information to the researcher. The sources of data in this study were teaching learning process activity using the Comic Strips and Board Game

\section{Research Method}

This research will apply classroom action research by Kemmis and Taggart. This research intend to improve students' Oral Languge Skills by using comic strips and Board Game. According to Kemmis and Taggart stated that action research is a form research reflection self that collectively do researcher in a social situation in order to improve reasoning and justice of there on social or education practice. Based on theory on Classroom Action Research, it concluded that the classroom action research is working, the application and activities to fact finding in solve the problem of social situation in improving the quality of action and analyze to the treatment. Thus, it involved four steps, namely: planning, action, observation, and reflection with each of these activities being systematically and self critically implement and interrelate.

\section{Technique of Collecting the Data}

The data were collected as follows:

1. Observation

The first technique used to collect the data was observations. The researcher enters to the class and observed the situation. It was reported in the form of observation sheet.

2. Test

The researcher will do a PreTest and Post-Test. The pre-test is before the learning process using the media to measure students' understanding in speaking. Post-Test will be the second test after the teacher gives treatments to the students by using comic strip and Board Game.

3. Interview

Interview is a conversation aimed get information, usually it consist of two person or more. Interview was conduct to get information about students' 
problem and interest in learning English.

\section{Technique of Analyzing the Data}

There are two kinds of data in this research, namely qualitative data and quantitative data.

1. The qualitative data

The qualitative data were obtained from the interview with the lecturers based on the interview guide and the observation. The data from interview and observation were about the classroom condition, the learning teaching process, the problem faced, and the expected solutions. The comments and suggestions from the lecturer were also described qualitatively.

2. The quantitative data The quantitative data were collected from the tabulation of the students' achievement in speaking skills. The result of the score from the Instrument of Writing the Dialog and The instrument of Speaking.

Table 1. Instrument of Writing the Dialog

\begin{tabular}{|c|c|l|l|}
\hline No & Aspect & \multicolumn{1}{|c|}{ Criteria } & Score \\
\hline 1 & Content & The dialog covers all information needed & \\
\hline 2 & Vocabulary & The student uses appropriate vocabulary & \\
\hline 3 & Grammar & The student uses appropriate grammar. & \\
\hline 4 & Spelling & The student uses correct spelling. & $\begin{array}{l}\text { The student uses correct punctuation } \\
\text { (including capital letters, question marks, } \\
\text { exclamation marks) }\end{array}$ \\
\hline 5 & punctuation & Final Scores (=sum of all scores : 2) & \\
\hline & & s. &
\end{tabular}

Score: $1=$ very poor; $2=$ poor; $3=$ average; $4=\operatorname{good} ; 5=$ excellent

Table 2. Instrument of Speaking

\begin{tabular}{|c|c|l|c|}
\hline No & Aspect & Criteria & $\begin{array}{c}\text { Score } \\
\text { (1-5) }\end{array}$ \\
\hline 1 & Content & The student covers all expression needed & \\
\hline 2 & Language & $\begin{array}{l}\text { The students uses appropriate vocabulary } \\
\text { and grammar needed by the speech }\end{array}$ & \\
\hline
\end{tabular}




\begin{tabular}{|c|c|l|l|}
\hline 3 & Pronunciation & $\begin{array}{l}\text { The student uses appropriate intonation } \\
\text { and pronunciation, he/she says the } \\
\text { sentences, loudly, clearly and correctly. }\end{array}$ & \\
\hline 4 & Fluency & The student speaks fluently & \\
\hline 5 & Performance & $\begin{array}{l}\text { The student uses body language to support } \\
\text { his/her dialog }\end{array}$ & \\
\hline & & Final Scores (=sum of all scores $\mathbf{x}$ 4) & \\
\hline
\end{tabular}

Score: $1=$ very poor; $2=$ poor; $3=$ average; $4=$ good; $5=$ excellent

To determine the feasibility of the media, researcher used Likert Scale in analyzing the data. The researcher used the Likert Scals.
Finally, those data were changed into percentage of data. The formula used is as follow:

Total Score (n)

\section{Maximum Score $(\mathrm{N})$}

After that, the data were transformed into qualitative data with highest percentage of $100 \%$ and lowest percentage $\leq 55 \%$ The next was the data were described qualitatively, the range percentages and the quality levels are as follow:

Table 3. Range Percentage and Quality Level

\begin{tabular}{|c|c|}
\hline Percentage & Category \\
\hline $86 \%-100 \%$ & Very Good \\
\hline $75 \%-85 \%$ & Good \\
\hline $56 \%-74 \%$ & Fair \\
\hline$\leq 55 \%$ & Poor \\
\hline
\end{tabular}

\section{RESULTS AND DISCUSSION Research Findings}

In this study, the researcher would like to describe the result of cycle I and cycle II, as follows:

\section{Cycle I}

The results of cycle I was categorized into: plannning, action, observation, and reflection, as follows:

1. Planning

In this step, the researcher evaluates the syllabus, lesson plan and the existing oral language skills materials used for the students.

2. Action 
The first cycle was conducted the lesson by using the usual media, such as book.

3. Observation

The observation was done to observe how the student' behavior and what the studentse problem during the teaching learning process. From the result of observation, It was found that the some students' faced difficulties in speaking.

Table 4. The Result of Writing the Dialog

\begin{tabular}{|c|c|l|c|}
\hline No & Aspect & \multicolumn{1}{|c|}{ Criteria } & Score \\
\hline 1 & Content & The dialog covers all information needed & 2 \\
\hline 2 & Vocabulary & The student uses appropriate vocabulary & 3 \\
\hline 3 & Grammar & The student uses appropriate grammar. & 3 \\
\hline 4 & Spelling & The student uses correct spelling. & 3 \\
\hline 5 & punctuation & $\begin{array}{l}\text { The student uses correct punctuation } \\
\text { (including capital letters, question marks, } \\
\text { exclamation marks) }\end{array}$ & 3 \\
\hline \multicolumn{2}{|l|}{ Score: $1=$ very poor; 2= poor; 3 = average; 4= good; 5 = excellent } \\
\hline
\end{tabular}

Table 5. The Result of Speaking

\begin{tabular}{|c|c|l|c|}
\hline No & Aspect & \multicolumn{1}{|c|}{ Criteria } & $\begin{array}{c}\text { Score } \\
\text { (1-5) }\end{array}$ \\
\hline 1 & Content & The student covers all expression needed & 2 \\
\hline 2 & Language & $\begin{array}{l}\text { The students uses appropriate vocabulary } \\
\text { and grammar needed by the speech }\end{array}$ & 3 \\
\hline 4 & Pronunciation & $\begin{array}{l}\text { The student uses appropriate intonation } \\
\text { and pronunciation, he/she says the } \\
\text { sentences, loudly, clearly and correctly. }\end{array}$ & 3 \\
\hline 5 & Performance & $\begin{array}{l}\text { The student uses body language to support } \\
\text { his/her dialog }\end{array}$ & 3 \\
\hline & Final Scores (=sum of all scores x 4) & 52 \\
\hline
\end{tabular}


Score: $1=$ very poor; $2=$ poor; $3=$ average; $4=$ good; $5=$ excellent

Table 6. The Result Range Percentage and Quality Level

\begin{tabular}{|c|c|}
\hline Percentage & Category \\
\hline $86 \%-100 \%$ & Very Good \\
\hline $75 \%-85 \%$ & Good \\
\hline $56 \%-74 \%$ & Fair \\
\hline$\leq \mathbf{5 5 \%}$ & Poor \\
\hline
\end{tabular}

The researcher administered the speaking test to the students in order to know the students' ability before using the Comic Strips and Board Game. The result of the pre-test showed that the students' speaking skills was still low. Which means that their average was under $55 \%$. The students' who got point up 55 were 8, and 22 students' unsuccessful.

\section{Cycle II}

The aim of second cycle was to improve the students' score in speaking. The researcher added some activities in the second cycle that have done while teaching Oral Language Skills in four steps: planning, action, observing, and reflecting such as follow:

1. Planning In this phase, the researcher begun by identified the problem and the alternative to solve the problem, the researcher use the same material and using the Comic Strips and Board Game.

2. Action

In this cycle, the researcher explained more deeply about the material in supposed the students' could improve speaking by using Role Playing. The researcher used the strategy to make the students' more interested and developed their creativity and also more focused in the material using Comic Strips and Board Game. The researcher also created the supportive situation in the class during teaching learning process.

3. Observing

The activity of students' was observed. the result showed that most of the students' did not have problems anymore about the meaning of the words. They liked to read the Comic Strips and Board Game. They were active during teaching learning process and more enthusiastic than before.

It was showed from the mean of post-test in the second cycle was 88. And the higher score was 92. From the data, it indicated that using Comic Strips and Board Game in learning Oral Language Skills was effective, and the data above can be concluded that the students' have the improvement in speaking.

Table 7. the Result of Writing the Dialog 


\begin{tabular}{|c|c|l|c|}
\hline No & Aspect & \multicolumn{1}{|c|}{ Criteria } & Score \\
\hline 1 & Content & The dialog covers all information needed & 4 \\
\hline 2 & Vocabulary & The student uses appropriate vocabulary & 4 \\
\hline 3 & Grammar & The student uses appropriate grammar. & 4 \\
\hline 4 & Spelling & The student uses correct spelling. & 5 \\
\hline 5 & punctuation & $\begin{array}{l}\text { The student uses correct punctuation } \\
\text { (including capital letters, question marks, } \\
\text { exclamation marks) }\end{array}$ & 5 \\
\hline Score: $1=$ very poor; 2= poor; 3 = average; 4 = good; 5 = excellent
\end{tabular}

Table 8. The Result of Speaking

\begin{tabular}{|c|c|c|c|}
\hline No & Aspect & Criteria & $\begin{array}{c}\text { Score } \\
(1-5)\end{array}$ \\
\hline 1 & Content & The student covers all expression needed & 4 \\
\hline 2 & Language & $\begin{array}{l}\text { The students uses appropriate vocabulary } \\
\text { and grammar needed by the speech }\end{array}$ & 4 \\
\hline 3 & Pronunciation & $\begin{array}{l}\text { The student uses appropriate intonation } \\
\text { and pronunciation, he/she says the } \\
\text { sentences, loudly, clearly and correctly. }\end{array}$ & 5 \\
\hline 4 & Fluency & The student speaks fluently & 4 \\
\hline 5 & Performance & $\begin{array}{l}\text { The student uses body language to support } \\
\text { his/her dialog }\end{array}$ & 5 \\
\hline & & Final Scores (=sum of all scores $x$ 4) & 88 \\
\hline
\end{tabular}

Table 9. The Result Range Percentage and Quality Level

\begin{tabular}{|c|c|}
\hline Percentage & Category \\
\hline $86 \%-100 \%$ & Very Good \\
\hline
\end{tabular}




\begin{tabular}{|c|c|}
\hline $75 \%-85 \%$ & Good \\
\hline $56 \%-74 \%$ & Fair \\
\hline$\leq 55 \%$ & Poor \\
\hline
\end{tabular}

The average score of the result of speaking was $88 \%$ and it was categorized as Very Good.

\section{Reflection}

The feedback process from the action that has been done which taken from the result of interview, observation, and test. The researcher concluded that most of students' score improved from the first test to the second test. It means that Comic Strips and Board Game were effective and suitable in improving the students' speaking skills.

\section{DISCUSSION}

The research was conducted to find out the improvement of students' Oral Language Skills through comic strips and Board Game. The comic strips and Board Game were one of many media which can be used by the researcher in teaching English especially to help the students in Speaking.

The research that had been done by the researcher indicated that comic strips and Board Game were effective or could be used in teaching. It could be seen from the improvement of students' score from the Cycle I and Cycle 2. The improvement because of the lecturer knew how to control the class. Besides that, comic strips and Board Game helped the students to understand the material easily. Based on quantitative data could be seen the students' achievement in speaking. It was showed from the mean of pre-test was 52 and the mean of post-test was 88 . Based on the data qualitative, it was taken from the result of observation and interview. It was found that the class ran effectively and the students more active while learning. The students focused and paid attention to the lecturer when the lecturer explained about the lesson. And the students were enthusiastic and interested in learning English. Then, there was the improvement of the students' English score. It could be proven from the result of observation that the students could activate in learning.

\section{CONCLUSIONS AND SUGGESTIONS}

Based on the results and analysis of the research, some conclusion and suggestions are described as follows:

\section{Conclusions}

1. Generally, the existing Oral Language Skills material was less relevant with the needs of the first grade students of English Department. In term of topics, they are not relevant with the speaking activities, it makes the students are less motivated in learning English. In term of practices, they are not well designed, the practices do not help and ease the students to promote their speaking skill, and as a result their speaking skill is low. 
2. Comic Strips and Board Game were designed based on need analysis of the students. Role playing method was used in the teaching learning process. Role playing was provided by group activity, so the students are more active while learning English. Based on the result of the research, Comic Strips and Board game can improve the students English score

\section{Suggestions}

1. Lecturer

The lecturer considers the students' needs in choosing the learning materials. The lecturer should be able and creative to provide the media in order to make students be easier to understand in learning oral language skills and make the successful learning process in the class.

2.. Students

The students should get appropriate textbook and related to their needs. It can make them easy to learn English and interest with it.

Comic Strips and Board Game will help the students' into two goals: comprehending English and training to speak English. The media also make them active and creative in team or individual.

3. Other researcher

Other researcher should find many references to support in developing media in teaching. The questions of questionnaire should be considered to give the students' chance to deliver their wants in learning English specifically on Oral Language Skills.

\section{REFERENCES}

Arsyad, A. 2011. Media Pembelajaran. Jakarta. PT. Raja Grafindo Persada.

Arikunto, S. 2002. Metodologi Penelitian. Pt Rineka Cipta. Jakarta

Arikunto, S. 2006. Prosedur Penelitian: suatu pendekatan praktek. Rineka

Cipta. Jakarta

Agustina, E. 2016. Pengembangan Media Gambar Seri Untuk Meningkatkan

Kosakata Siswa Dalam

Keterampilan Berbahasa Inggris. Jurnal

Carly, S. 2010. The Advantages of Learning Games for Kids. http://www.livestrong.com accessed on August, 19th 2015.

Hastuti, S. 1993. Buku Pegangan Kuliah Pendidikan Bahasa Indonesia. Yogyakarta: UPP IKIP Yogyakarta

Johana, M.2007. Komik Sebagai Pengajaran. Dictionary Labour Talk.

Jones, L. 2008. Let's Talk. Cambridge University Press. Cambridge.

Kemmis,S \& Mc Taggar,R.1992. The action research planner. Australia: Deakin University Press.

Maidar G. Arsjad dan Mukti. 1991. Pembinaan Kemampuan 
Berbicara Bahasa Indonesia. Jakarta: Erlangga.

McCloud, S. 2002. Understanding Comics. Jakarta. KPG.

Nurbadri. 2011. English Games Untuk Meningkatkan Speaking Skill dan Motivasi Siswa. Jurnal.

Pritchard, D. B. 1994. "Snakes and ladders", the Family Book of Games. Brock

Hampton Press.

Purwanti, E .2002 Perkembangan Peserta Didik. Malang: UMM Press.

Rahmawati, I.N. 2012. Improving the Fourth Grade Students' Speaking Skill through Board Games at SD Muhammadiyah Pepe Bantul. A Thesis. Yogyakarta: English Education Department, Faculty of Languages and Arts, Yogyakarta State University.

Sabarti Akhadiah, dkk .1993.Bahasa Indonesia $1 . \quad$ Jakarta: Depdikbud.

Scorviano, M. 2010. Sejarah Board Game dan Psikologi Permainan Board Game. Jakarta

Susilana, R dan Riyana, C. 2009. Media Pembelajaran: Hakikat,. Pengembangan, Pemanfaatan, dan Penilaian. Bandung: CV Wacana Prima.

Suyanto. 2005. Konsep Dasar Anak usia Dini. Departemen Pendidikan Nasional. Jakarta
Rusman. 2013. Belajar dan Pembelajaraan Berbasis Komputer. Bandung: Alfabeta

Wathy. 2006. Meningkatkan Kemampuan Berbicara Siswa Melalui Board Game. Jurnal.

Damanik, D., Panjaitan, J., \& Simangunsong, I. (2020). PENGARUH MODEL PEMBELAJARAN KOOPERATIF NHT (NUMBERED HEAD TOGETHER) BERBANTUAN MIND MAPPING TERHADAP HASIL BELAJAR FISIKA PADA MATERI POKOK LISTRIK DINAMIS. Jurnal Darma Agung, 28(1), 92 - 99. doi:10.46930/ojsuda.v28i1.467

Purba, D., \& Sihombing, H. (2020). IMPROVING STUDENTS'WRITING
ABILITY IN DARMA AGUNG UNIVERSITY. Jurnal Darma Agung, 28(1), 145-155. doi:10.46930/ojsuda.v28i1.602 